Arkhais, Vol. 06 No. 1 Januari-Juni 2015

\title{
KERABATAN BAHASA BATAK TOBA DAN BAHASA BATAK ANGKOLA SUATU KAJIAN LINGUISTIK HISTORIS KOMPARATIF
}

\section{Gokma Mualita}

\begin{abstract}
Abstrak. Penelitian ini bertujuan untuk mengetahui hubungan kekerabatan antara Bahasa Batak Toba dan Bahasa Batak Angkola, dengan melakukan perbandingan antara Bahasa Batak Angkola dan Bahasa Batak Toba berdasarkan 200 kata Morris Swadesh. Penelitian ini juga meneliti bagaimana penggunaan bahasa, kegiatan berbahasa, dan sikap berbahasa oleh beberapa masyarakat yang ada di desa asal kedua bahasa tersebut. Penelitian ini dilaksanakan di Sumatera Utara pada bulan Februari 2015. Objek penelitian merupakan enam informan yang memenuhi kriteria, masing-masing bahasa baik itu Bahasa Batak Toba dan Bahasa Batak Angkola mengambil sampel tiga informan. Fokus penelitian adalah kedua bahasa itu sendiri yaitu Bahasa Batak Toba dan Bahasa Batak Angkola. Instrumen penelitian adalah peneliti sendiri dibantu dengan tabel analisis kerja daftar 200 kata Leksikostatistik Morris Swadesh dan tabel angket pemakaian bahasa, sikap bahasa, dan kegiatan berbahasa informan. Metode yang digunakan adalah metode kualitatif dan kuantitatif. Hasil penelitian ini menunjukkan bahwa Bahasa Batak Toba dan Bahasa Batak Angkola memiliki hubungan kekerabatan dilihat dari 200 kosakata dasar Morris Swadesh yang telah dibandingkan, melalui hasil perbandingan terdapat 114 kata yang berkerabat yang terdiri dari 89 kata yang berkerabat identik dan 25 kata yang berkerabat namun mengalami perubahan bunyi baik bunyi vokal maupun bunyi konsonan. Tingkat hubungan kekerabatan antara Bahasa Batak Toba dengan Bahasa Batak Angkola ini dikategorikan sedang karena dari hasil presentase yang dihitung terdapat 57\% dari 200 glos yang diperoleh. Tahun pisah kedua bahasa tersebut dari sebuah bahasa induk terjadi pada tahun $681 \mathrm{M}$. Hasil Angketpun membuktikan informan sangat menjunjung tinggi bahasa daerah mereka.
\end{abstract}

Kata Kunci: Kekerabatan Bahasa, Bahasa Batak Toba, Bahasa Batak Angkola, Penggunaan Bahasa, Kegiatan Berbahasa, Sikap Berbahasa.

\section{PENDAHULUAN}

Indonesia merupakan negara besar, tidak hanya dari segi wilayah dan jumlah penduduk, tetapi juga dari segi jumlah bahasa (daerah) di Indonesia terdapat 746 bahasa daerah. Berdasarkan jumlah tersebut terdapat 442 bahasa daerah yang telah dipetakan dan dipublikasikan pada peta bahasa Negara Kesatuan Republik Indonesia.

Bahasa merupakan tanda yang jelas dari keluarga dan bangsa, dari pembicaraan seseorang kita tidak saja dapat menangkap keinginannya, tetapi juga motif keinginannya, latar belakang pendidikannya, pergaulannya, adat istiadatnya, dan lain sebagainya. Bahasa daerah disebut sebagai bahasa pertama, karena bahasa daerah merupakan bahasa seharihari yang di mana dipakai dalam lingkungan keluarga dan pada umumnya juga di daerah tempat anak itu tinggal, karena biasanya setiap rumah tangga pasti menggunakan bahasa dari daerah mereka masing-masing. Bahasa daerah di lingkungan mereka tinggal tentunya tidak dapat dipakai di tempat lain yang tidak memahami bahasa mereka.

Bahasa daerah berfungsi sebagai lambang kebanggaan daerah, lambang identitas daerah dan alat perhubungan di lingkungan keluarga masyarakat dan daerah. Sesuai 
dengan penjelasan pasal 36 Undang-Undang Dasar 1945, bahasa-bahasa di Indonesia seperti bahasa Jawa, Bahasa Sunda, dan Bahasa Batak berkedudukan sebagai bahasa daerah dan merupakan unsur kebudayaan nasional (Hasan Alwi: 2011)

Indonesia memiliki berbagai macam suku dan banyak sekali bahasa daerah seperti yang dikemukakan di atas, serta dari beratus-ratus bahasa daerah tersebut telah dipetakan dan menjadi bahasa ibu salah satunya yaitu suku Batak yang memiliki keberagaman bahasa di dalamnya. Suku Batak merupakan suku yang berasal dari pulau Sumatra Utara, suku Batak sendiri memakai bahasa Batak sebagai bahasa ibu mereka. Bahasa-bahasa Batak terdiri dari tiga rumpun, yaitu:

1. Rumpun Utara : Bahasa Karo, Bahasa Dairi, Bahasa Alas;

2. Rumpun Tengah : Bahasa Simalungun;

3. Rumpun Selatan : Bahasa Toba, Bahasa Angkola, dan Bahasa

Mandailing.

Orang Batak Toba menyebut bahasanya hata Batak, orang Simalungun menyebut bahasa mereka sahap Simalungun, orang Karo menyebut bahasanya cakap Karo. orang Mandailing dan Angkola menyebut bahasa mereka saro Mandailing dan saro Angkola (Basyral Hamidi Harahap: 1993).

Menurut sensus penduduk Indonesia tahun 1990, pemakai bahasa Batak sebagai bahasa sehar-hari berjumlah 3.304.286 yang selengkapnya dijabarkan pada tabel berikut:

Tabel Tabel pemakaian Bahasa Batak 1990

\begin{tabular}{llllll}
\hline Umur & Pedesaan & Kota & Laki-laki & Perempuan & Total \\
\hline $5-9$ & 493.639 & 70.116 & 287.813 & 275.942 & 563.755 \\
$10-14$ & 477.349 & $\mathbf{6 3 . 7 1 7}$ & 292.182 & 248.884 & 541.066 \\
$15-24$ & 567.207 & 129.679 & 344.671 & 452.215 & 696.886 \\
$25-49$ & 835.280 & 186.849 & 484.049 & 538.035 & 1.022 .129 \\
$>50$ & 412.327 & $\mathbf{6 8 . 1 2 3}$ & 217.332 & 263.118 & 480.286 \\
\hline Jumlah & $\mathbf{2 . 7 8 5 . 8 0 2}$ & $\mathbf{5 1 8 . 4 8 4}$ & 1.626 .092 & 1.678 .194 & 3.304 .286 \\
\hline
\end{tabular}

Sumber: Biro Pusat Statistik, (1991)

Informasi ini menegaskan bahwa orang Batak dari berbagai kelompok itu sebagian besar masih tetap mempertahankan kebudayaannya yang termasuk dalam bahasanya hal ini terbukti dari angka persentase $81.39 \%$ penutur Bahasa Batak masih menetap di derah pedesaan yang masih tradisional (Basyral Hamidi Harahap: 1993).

Bahasa Batak Toba ketersebarannya memenuhi di wilayah Kabupaten Tapanuli Utara pulau Sumatera, yang secara administratif terdiri atas 15 kecamatan yaitu:

1) Kecamatan Tarutung;

2) Kecamatan Adiankoting;

3) Kecamatan Pahae Julu;

4) Kecamatan Pahae Jae;

5) Kecamatan Simagumban;

6) Kecamatan Purba Tua;

7) Kecamatan Siatas Barita;

8) Kecamatan Sipahutar;

9) Kecamatan Pangaribuan;

10) Kecamatan Garoga;

11) Kecamatan Sipoholon;

12) Kecamatan Pagaran; 
Arkhais, Vol. 06 No. 1 Januari-Juni 2015

13) Kecamatan Siborongborong;

14) Kecamatan Muara;

15) Kecamatan Parmonangan.

Meskipun di wilayah tersebut merupakan ketersebaran Bahasa Batak Toba, tidak memungkingkan bahwa di wilayah Tapanuli lain tidak terdapat suku Batak Toba. Hal ini dikarenakan budaya suku Batak yang merantau di lain daerah.

Sedangkan Bahasa Batak Angkola ketersebarannya terdapat di daerah Tapanuli Selatan kecamatan Batang Angkola, Sipirok, Padang Sidempuan serta Padang Lawas. Angkola merupakan cabang dari Mandailing karena Angkola masih dalam satu kabupaten dengan Mandailing, tetapi kekerabatan bahasa Angkola lebih dekat dengan Bahasa Batak Toba dikarenakan kontak bahasa dari segi geografi yang berbatasan dengan Bahasa Batak Toba. Karena adanya kekerabatan maka dari itulah adanya suatu ilmu yang mebandingkan bahasa yang berkerebat tersebut yaitu Linguistik Historis Komparatif.

\section{METODE PENELITIAN}

Metode yang digunakan dalam penelitian ini adalah metode kualitatif dan kuantitatif. Metode kuantitatif yaitu leksikostatistik untuk menghitung persentase perangkat kognat (kekerabatan) dan meghitung tahun pisah kedua bahasa tersebut. Metode kualitatif yaitu menentukan bentuk kognat antara Bahasa Batak Toba dengan Bahasa Batak Angkola, menentukan dan mendeskripsikan perubahan bunyi-bunyi atau bagaimana koinformansi bunyi antara Bahasa Batak Toba dengan Bahasa Batak Angkola, menentukan pemakaian bahasa, kegiatan berbahasa, dan sikap berbahasa masyarakat Batak Toba dan Batak Angkola.

\section{HASIL DAN PEMBAHASAN}

Penelitian ini menguraikan data kekerabatan bahasa berupa 200 kata Morris Swadesh yang diambil dari Bahasa Batak Toba dan Bahasa Batak Angkola, pada deksripsi data menjelaskan tentang deksripsi informan, deskripsi kekerabatan Bahasa Batak Toba dan Bahasa Batak Angkola, data kata-kata kerabat (kognat), perubahan bunyi-bunyi vokal kata-kata kognat, data perubahan bunyi konsonan, perhitungan tahun pisah, tabel pemakaian bahasa, sikap bahasa, dan penggunaan bahasa oleh informan.

Dalam memperoleh informasi dalam penelitian ini, informan yang dibutuhkan yaitu penutur asli, penduduk asli, usia dewasa, minimal taman SD, sehat fisik dan mental, tidak memiliki cacat artikulatoris dan status sosial menengah ke bawah. Maka dari itu peneliti mendapatkan informan sesuai dengan kriteria di atas yang berjumlah enam orang, masingmasing tiga informan dari Bahasa Batak Toba dan Bahasa Batak Angkola. Informan yang berasal dari bahasa batak Toba yang pertama yaitu Jek Ferdy Aruan berumur 33 tahun saat ini berprofesi sebagai peladang dan peternak, pendidikan terakhir yaitu SMK; yang kedua yaitu Tianggur Aruam berumur 67 tahun saat ini berprofesi sebagai petani, pendidikan terakhir yaitu SD; yang ketiga bernama Hermanto Hutapean berumur 40 tahun saat ini berprofesi sebagai kepala desa, pendidikan terakhir yaitu SMA, ketiga informan ini lahir dan berdomisili di Desa Banuarea Hutapea, Kecamatan Tarutung.

Tiga informan berikut ini merupakan informan yang berasal dari Bahasa Batak Angkola. Informan pertama yang bernama Norma Dongoran berumur 40 tahun saat ini berprofesi sebagai penenun dan petani, pendidikan terakhir yaitu SMP dan lahir di Paranjulu, Sipirok; yang kedua yaitu Peter Harahap berumur 65 tahun, pendidikan terakhir yaitu SMA dan lahir di Banjar Toba, Sipirok; yang ketiga bernama Batara Suangkopon Siregar berumur 57 tahun saat ini berprofesi sebagai ketua adat (harajaon) dan pedagang, 
pendidikan terakhir SMP beliau sendiri lahir di Parausorat, Sipirok. Ketiga informan berdomisili di Desa Parausorat, Kecamatan Sipirok.

Berdasarkan data kekerabatan bahasa Bahasa Batak Toba dan Bahasa Batak Angkola telah ditemukan dari 200 kata terdapat 114 kata yang berkerabat, baik itu kata yang berkerabat identik atau yang mengalami perubahan bunyi vokal maupun konsonan, kata yang berkerabat identik dan makna sama sebanyak 89 kata sedangkan kata yang mengalami perubahan bunyi vokal maupun konsonan namun makna sama terdapat 25 kata.

Perubahan bunyi vokal yang terdapat pada data kekerabatan (kognat) adalah sebanyak 14 perubahan bunyi vokal dalam 17 kata sedangkan perubahan bunyi konsonan yang terdapat dalam data kekerabatan adalah sebanyak 20 perubahan bunyi konsonan dalam 17 kata , beberapa di antara kata-kata kognat perubahan konsonan dan vokal dapat terjadi dalam kata yang sama atau lebih tepatnya satu kata bisa terjadi dua perubahan sekaligus baik itu konsonan maupun vokal. Melalui perubahan bunyi tersebut setelah itu dilakukanlah penghitungan tahun pisah.

Dari 200 kata menurut tabel di atas ditentukan ada 114 yang kognat atau berkerabat yang mewakili:

a. bunyi sama total (identik) $\quad: 89$ kata

b. kemiripan bunyi-makna sama : 25 kata

jumlah kata berkerabat : 114, setelah itu dibentuk menjadi persentase untuk menghitung tahun pisah:

$\begin{array}{ll}c= & \frac{114 \times 100 \%}{200} \\ = & 57 \%\end{array}$

Persentase kekerabatan Bahasa Batak Toba dan Bahasa Batak Angkolah adalah 57\%..

Selanjutnya, untuk menghitung tahun pisah dengan menggunakan rumus sebagai berikut:

$\mathrm{t}=\log \mathrm{c}$

$\overline{2 \log r}$

Keterangan:

$\mathrm{t}=$ lama waktu berpisah

$\mathrm{c}=$ persentase kata berkerabat

$\mathrm{r}=$ konstan/ indeks Morris Swadesh

$\log =\operatorname{logaritma}$

Setelah melakukan wawancara berdasarkan 200 kata Morris Swadesh dengan beberapa informan dari kedua bahasa didapatkan jumlah kata berkerabat baik itu yang sama total atau bunyi mirip namun makna sama atau bunyi bergeser namun makna sama. Setelah didapatkannya jumlah kata berkerabat untuk mendapatkan tahun pisah kedua bahasa tersebut dilakukan penghitungan berdasarkan rumus di atas yaitu sebagai berikut:

$$
\begin{aligned}
\mathrm{t} & =\frac{\log \mathrm{c}}{2 \log r} \\
& =\frac{\log 57 \%}{2 \log 81 \%} \\
& =\frac{-0,2441}{2(-0,0915)} \\
& =\frac{-0,2441}{-0,183} \\
& =1,334 \times 1000 \\
= & 1334
\end{aligned}
$$


Arkhais, Vol. 06 No. 1 Januari-Juni 2015

Tahun pisah adalah $2015-1334=681 \mathrm{M}$

Jadi, Bahasa Batak Toba berpisah dengan Bahasa Batak Angkola dari sebuah bahasa Induk terjadi pada tahun $681 \mathrm{M}$.

Hasil penelitian ini juga melihat kapan tahun pisah antara kedua bahasa dengan bahasa induknya, setelah kata-kata berkerabat atau kognat dihitung diketahui tahun pisah antara Bahasa Batak Toba dan Bahasa Batak Angkola dari sebuah bahasa induk pada tahun 681 Masehi. Penelitian ini juga memaparkan bagaimana sikap bahasa, penggunaan bahasa dan pemakaian bahasa oleh para informan, ini menegaskan bagaimana penggunaan bahasa daerah bagi mereka sangat penting karena penggunaan bahasa daerah sebagai bahasa sehari-hari bagi mereka dan juga para informan kebanyakan jarang menggunakan bahasa Indonesia kecuali dengan orang yang baru di kenalnya.

Bahasa Batak Toba dan Bahasa Batak Angkola memiliki ciri kekerabatan bahasa, yang pertama terdapat 114 kata yang berkerabat (kognat), dan dari kekerabatan bahasa tersebut terdapat beberapa kata yang berkerabat identik dan makna sama tetapi mengalami perubahan ini, hal ini juga dikarenakan letak geografis Batak Toba dan Batak Angkola tidak terlalu jauh atau berdekatan.Berdasarkan deskripsi kekerabatan yang telah di jelaskan dan dipaparkan dalam tabel kekerabatan (kognat) ditemukan dari 200 kata terdapat 114 kata yang berkerabat, 84 kata yang berkerabat identik dan 30 kata yang mengalami pergeseran bunyi vokal maupun konsonan tetapi makna sama.

Jumlah kekerabatan yang telah diketahui, kemudian dihitung guna mencari tahun pisah kedua bahasa yaitu Bahasa Batak Toba dan Bahasa Batak Angkola dari bahasa induknya dengan menggunakan rumus yang telah dijelaskan sebelumnya yaitu pada tahun 681 Masehi.

\section{KESIMPULAN}

Berdasarkan deskripsi data, deskripsi informan, analisis data, pembahasan penelitian maka ditarik kesimpulan pada penelitian kekerabatan Bahasa Batak Toba dan Bahasa Batak Angkola, di antaranya:

Kedua bahasa memiliki hubungan kekerabatan yang dibandingkan dari 200 kata Morris Swadesh, dari hasil perbandingan ditemukan 114 kata yang memiliki hubungan yang berkerabat di antaranya yaitu 89 kata yang berkerabat identik dan 25 kata yang berkerabat namun mengalami perubahan bunyi baik bunyi vokal maupun bunyi konsonan.

Kedua bahasa yang berkerabat tersebut telah diketahui tahun pisahnya dengan menggunakan rumus penghitungan tahun pisah untuk mengetahui kapan kedua bahasa tersebut berpisah dari bahasa induknya, dan hasilnya adalah $681 \mathrm{M}$.

Hubungan tingkat kekerabatan Bahasa Batak Toba dan Bahasa Batak Angkola terbilang sedang, karena hasil dari penghitungan didapatkan persentasenya yaitu $57 \%$ dari daftar 200 kata Morris Swadesh.

Diketahui perubahan bunyi vokal antara Bahasa Batak Toba dan Bahasa Batak Angkola, diperoleh 14 perubahan bunyi vokal yaitu $\varnothing>i, \varnothing>a, a>\varnothing, i>\varnothing, i>u, \varepsilon>a, a>i$, $\mathrm{O}>\mathrm{\rho}, \mathrm{o}>\varnothing, \mathrm{o}>\mathrm{O}, \mathrm{\rho}>\mathrm{i}, \mathrm{\jmath}>\mathrm{a}, \mathrm{u}>\mathrm{o}$ dan $\mathrm{u}>\varnothing$, sedangkan perubahan bunyi konsonan antara Bahasa Batak Toba dan Bahasa Batak Angkola diperoleh 20 perubahan bunyi konsonan yaitu $\varnothing>\mathrm{m}, \varnothing>\mathrm{y}, \mathrm{k}>$ ?, $\varnothing>\mathrm{r}, \varnothing>\mathrm{s}, \varnothing>\mathrm{t}, \varnothing>\mathrm{y}, \varnothing>\mathrm{\eta}, \mathrm{b}>\mathrm{h}, \mathrm{j}>\mathrm{d}, \mathrm{k}>\varnothing, \mathrm{k}>$ ?, $\mathrm{k}>\mathrm{\eta}, \mathrm{l}>\mathrm{r}, \mathrm{m}>\varnothing$, $\mathrm{n}>\varnothing, \mathrm{r}>\varnothing, \mathrm{t}>\varnothing$, dan $\mathrm{p}>\varnothing$. Kata yang tidak memiliki hubungan kekerabatan sejumlah 86 kata.

Berdasarkan hasil angket informan diperoleh informasi mengenai pemakaian bahasa, kegiatan berbahasa, dan sikap berbahasa dari keenam informan, yaitu (1) Berdasarkan pemakaian bahasa keenam informan rata-rata keenam informan menggunakan 
Arkhais, Vol. 06 No. 1 Januari-Juni 2015

bahasa daerah dengan keluarga dan saudaranya baik itu di dalam rumah maupun di luar rumah, informanpun menggunakan bahasa indonesia dan bahasa daerah di tempat pekerjaan ataupun di tempat ibadah, akan tetapi jika dengan orang yang baru dikenal informan tidak menggunakan bahasa daerah. (2) Berdasarkan kegiatan berbahasa informan diperoleh informasi bahwa keenam informan tidak sering membaca berita dan artikel di koran maupun menyikam berita di RCTI ataupun TV One dan saat membaca ataupun menyimak berita rata-rata informan tidak memerhatikan kaidah bahasanya. (3) Berdasarkan sikap berbahasa informan diperoleh informasi bahwa informan menyetuji jika Bahasa Indonesia memudahkan pergaulan dan dapat mencerdaskan daerah, dan informanpun menyetujui bahwa penggunaan bahasa daerah memudahkan pergaulan serta lebih sopan jika digunakan dengan teman sekampung, informanpun lebih khusuk apabila berdoa menggunakan bahasa daerah, sebisa mungkin informan akan mencari menantu bagi anak-anaknya orang sedaerah. Keenam informan tidak menyetujui beberapa hal, yaitu penggunaan bahasa asing mempermudah memperoleh pekerjaan, penggunaan bahasa Indonesia memberi kesan kurang terpelajar, bahasa Indonesia nantinya akan menggeser bahasa ibu mereka atau bahasa daerah, penggunaan bahasa asing menambah kepercayaan diri, lama kelamaan bahasa asing akan menggantikan bahasa daerah, semakin lama semakin sering menggunakan bahasa Indonesia, apabila menjadi pejabat akan mengharuskan anak buah berbahasa daerah dan bahasa asing. Maka dari itu dapat disimpulkan bahwa informan memiliki kesetiaan berbahasa, mempertahan bahasanya dan menjunjung budayanya dalam bahasa.

\section{DAFTAR RUJUKAN}

Alwi, Hasan.2011 Butir-Butor Perencanaan Bahasa. Jakarta: Badan Pengembangan dan Pembinaan Bahasa Kementrian Pendidikan Dana kebudayaan.

Bangun, Kabar. 1984. Georgrafi Dialek Bahasa Batak Toba, Jakarta: Pusat Pembinaan dan pengembangan Bahasa Departemen Pendidikan kebudayaan Jakarta

Chaer, Abdul. 2009. Fonologi Bahasa Indonesia. Jakarta: Rineka Cipta.

Chaer Abdul, Leonie Agusta, 2004. Sosiolinguistik Perkenalan Awal. Jakarta

Harahap, Basyral Hamidy,dkk. 1993. Horja Adat Istiadat Dalihan Natolu. Jakarta: Parsadaan Marga Harahap Dohot Anakboruna di Jakarta Sahumaliangna

HP, Achmad. 1996. Materi Ajar Linguistik Umum Jakarta: Universitas Terbuka

HP, Achmad. Kedudukan dan Peranan Fonologi. Jakarta: Universitas Negeri Jakarta

Keraf, Gorys. 1990. Linguistik Bandingan Tipologis. Jakarta: Gramedia

Keraf, Gorys. 1991. Linguistik Bandingan Historis. Jakarta: Gramedia.

M.S, Mahsun. 2007. Linguistik Historis Komparatif. Yogyakarta: Gama Media.

Parera ,Jos Daniel. 1991 Kajian Linguistik Umum Historis Komparatif dan Tipologi Struktural. Jakarta: Erlangga. 
Arkhais, Vol. 06 No. 1 Januari-Juni 2015

Siahaan, Nalom. 1975 Morfologi Bahasa Batak Toba. Depok: Fakultas Sastra Universitas Indonesia.

Suwandi, Sarwiji. 2008. Serbalinguistik. Surakarta: LPP UNS dan UNS PRESS

Syukur,Abdul. Linguistik Komparatif Sajian Bunga Rampai. Jakarta: Usaha Nasional.

Tumpal H., Jawasi Naibaho. 1997. Fonologi Bahasa Angkola. Jakarta: Departemen Pendidikan dan Kebudayaan.

Verhaar, J.W.M. 1999 Asas-asas Linguistik Umum Yogyakarta: Gajah Mada Univerisity Press. 